21 Manoach DS, Ketwaroo GA, Polli FE, Thakkar KN, Barton JJ, Goff DC, et al. Reduced microstructural integrity of the white matter underlying anterior cingulate cortex is associated with increased saccadic latency in schizophrenia. Neuroimage 2007; 37: 599-610.

22 Shergill SS, Kanaan RA, Chitnis XA, O'Daly O, Jones DK, Frangou S, et al. A diffusion tensor imaging study of fasciculi in schizophrenia. Am J Psychiatry 2007; 164: 467-73.

23 American Psychiatric Association. Diagnostic and Statistical Manual of Mental Disorders (4th edn) (DSM-IV). APA, 1994.

24 Office of Population Censuses and Surveys. Standard Occupational Classification. Her Majesty's Stationery Office, 1991.

25 Annett M. A classification of hand preference by association analysis. Br J Psychol 1970; 61: 303-21.

26 Nelson HE, Willison JR. National Adult Reading Test (Part II): Test Manual (2nd edn). nferNelson, 1991.

27 First M, Spitzer R, Gibbon M, Williams J. Structured Clinical Interview for DSM-IV Axis I Disorders, Patient Edition (SCID-I/P) (Version 2.0). New York State Psychiatric Institute, 1995.

28 Bezchlibnyk-Butler KZ, Jeffries JJ (eds). Clinical Handbook of Psychotropic Drugs, (10th edn): 84-8. Hogrefe \& Huber Publishers, 2000.

29 Kay SR, Fiszbein A, Opler LA. The positive and negative syndrome scale (PANSS) for schizophrenia. Schizophr Bull 1987; 13: 261-76.

30 Basser PJ, Mattiello J, LeBihan D. Estimation of the effective self-diffusion tensor from the NMR spin echo. J Magn Reson B 1994; 103: 247-54.

31 Good CD, Johnsrude IS, Ashburner J, Henson RN, Friston KJ, Frackowiak RS A voxel-based morphometric study of ageing in 465 normal adult human brains. Neuroimage 2001; 14: 21-36.

32 Bullmore ET, Suckling J, Overmeyer S, Rabe-Hesketh S, Taylor E, Brammer MJ. Global, voxel, and cluster tests, by theory and permutation, for a difference between two groups of structural MR images of the brain. IEEE Trans Med Imaging 1999; 18: 32-42.

33 Talairach J, Tournoux P. Co-Planar Stereotaxic Atlas of the Human Brain Thieme, 1988

34 Mori S, Wanaka S, Nagae-Poetscher LM, van Zijl PCM. MRI Atlas of Human White Matter. Elsevier Science, 2005

35 Kanaan RA, Kim JS, Kaufmann WE, Pearlson GD, Barker GJ, McGuire PK. Diffusion tensor imaging in schizophrenia. Biol Psychiatry 2005; 58: 921-9.

36 Kyriakopoulos M, Bargiotas T, Barker GJ, Frangou S. Diffusion tensor imaging in schizophrenia. Eur Psychiatry 2008; 23: 255-73.

37 Lebel C, Walker L, Leemans A, Phillips L, Beaulieu C. Microstructural maturation of the human brain from childhood to adulthood. Neuroimage 2008; 40: 1044-55.

38 Jacobs B, Driscoll L, Schall M. Life-span dendritic and spine changes in areas 10 and 18 of human cortex: a quantitative Golgi study. J Comp Neurol 1997; 386: $661-8$.

39 Davis KL, Stewart DG, Friedman Jl, Buchsbaum M, Harvey PD, Hof PR, et al. White matter changes in schizophrenia: evidence for myelin-related dysfunction. Arch Gen Psychiatry 2003; 60: 443-56.

40 Rapoport J, Addington J, Frangou S. The neurodevelopmental model of schizophrenia: update 2005. Mol Psychiatry 2005; 10: 434-49.

41 Addington AM, Gornick M, Duckworth J, Sporn A, Gogtay N, Bobb A, et al. GAD1 (2q31.1), which encodes glutamic acid decarboxylase (GAD67), is associated with childhood-onset schizophrenia and cortical gray matter volume loss. Mol Psychiatry 2005; 10: 581-8.

42 Cheung V, Cheung C, McAlonan GM, Deng Y, Wong JG, Yip L, et al. A diffusion tensor imaging study of structural dysconnectivity in never-medicated, firstepisode schizophrenia. Psychol Med 2008; 38: 877-85.

43 Wechsler D. Wechsler Adult Intelligence Scale, (3rd edn). Psychological Corporation, 1997

\title{
Sean Spence
}

Jason Bourne (Matt Damon, the Bourne film trilogy) is an assassin who cannot recall his past. Discovered floating in the Mediterranean, bullets in his back, he miraculously recovers, surviving serial confrontations, before recapturing his identity. Bourne's is a psychogenic amnesia: he retains new information, his use of concepts is preserved, he is fluent in several languages, his motor skills are exceptional. Indeed, it is his 'procedural' memory that betrays his former life. If confronted, he summons up precision violence, seemingly out of nowhere. But can his recovered 'self' atone for its past? An act of contrition closes the second film. 